\title{
System Ontology and Descriptionism - Bertalanffy's View and New Developments.
}

\section{Klaus Kornwachs}

Brandenburg Technical University Cottbus, Chair for Philosophy of Technology, D - 03044 Cottbus; Humboldt Centre for Human Studies, University UIm, D - 89069 Ulm. E-mail: korn@tu-cottbus.de.

\begin{abstract}
After a first historical sketch about the rise of system ontology, some problems with naturalizing the system concept are worked out: -In different ontological positions the danger of essentialism is actual. This holds also for a certain interpretation of evolution that is suspected to be an essentialism? Bertalanffy's view is set into contrast to this positions -the constructivist approach. This gives rise to introduce the authors notion of descriptionisms as it is proposed and revisited here. The notions of system surface, of the
\end{abstract}

processes of system modeling and system control serve to contrast the reality of descriptions with unnecessary ontological commitments.

Keywords: systems theory, ontology, descriptionism, Ludwig von Bertalanffy

Reviewed and extended paper, presented at the Ludwig van Bertalanffy Anniversary Conference Unity through Diversity, Nov $1^{\text {rst }}-4^{\text {th }}, 2001$ Technical University of Vienna. Session: Evolution in System Thinking (Friday, Nov. ${ }^{2 n d}, 2001$ ).

\section{Introduction - The Basic Problem}

Talking about systems is an ambiguous affair - are you talking about a real object or about a construct? This very simple minded alternative is very often put forward in discussions when dealing with basic concepts of system theory. There seems to be a basic tension between a system concept that is conceived as a methodological tool and a system concept that represents a system as an object or as a genuine entity within the world.

The intention of this paper is to figure out the conceptual anatomy of this alternative, to describe it more precisely and to confront this analysis with Bertalanffy's view which he has developed concerning system theory and its epistemological preconditions. 


\section{The Rise of System Ontology}

A first step to do so is to look for some historic predecessors of system ontology. ${ }^{1}$ The first system concepts have included systems as a means of description with the purpose "to order", "to induce order", "to detect order", or "to observe order" within a section of what we call reality. This relation between system concept and the notion of order seems to be very old. One may find it in pre-Socratic fragments as well as in medieval writings. ${ }^{2}$

The second concept includes system as an object or an entity with genuine properties like closeness, stability, growth, emergence of further properties not observed before, and with an existence that encompasses dynamics as becoming and vanishing, generation and corruption. ${ }^{3}$ Both concepts have a long history within the ongoing development of natural sciences and particular in philosophy as in philosophy of nature as well. The roots of this development may allow to suspect that system thinking was in earlier time a good candidate for a comprehensive theory of everything (respective explaining everything).

Only a few examples may illustrate this point of view. G. W. Leibniz intended with his "Monadology" to give an elementary theory of everything, every object and every process. ${ }^{4}$ Originally conceptualized to answer the question of substances in ontology together with a Theodizee (how a good God can allow or tolerate the evil within the world) all monads form a whole of being, made stable by a god that designed the best of possible worlds. This pre-stabilized harmony of the world was an order that gives the world the characteristic of an existing system and the pre-designed system structures were also the system's laws. Each monad is different from each other one such that they present a kind of subsystems and G. W. Leibniz introduced a certain kind of hierarchy between the different sorts of monads. Nevertheless no monad could substitute another one or be removed from the best of all worlds.

The reason why this example is stretched here may be given by the fact that in such a kind of system conception the real existing world or objects have the character of a system because they have been designed as systems. Thus systems are real things and they can be distinguished from each other and all systems form a giant super-system that rules everything. The system characteristic is due to the design that presents the best thinkable order. Here, order and existence coincide: order is not a perspective or result of an evaluation, but a genuine property of existing things and of the world. This concept may serve as a paradigm for what we call classical ontology.

R. Descartes changed the number of substances, simply reducing it to two: res extensa and res cogitans. ${ }^{5}$ Speaking about systems he refers to a complete and ordered set of knowledge. Not the things are systems, but our concepts about them. This is a dramatic change because it deontologizes the system concept and shifts the concept of order from ontology to description. The system of Pure Reason by I. $\mathrm{Kant}^{6}$ is an epistemological prerequisite that foregoes all possible human experience like Geometry, Aristotelian Syllogism or even Newton Mechanics. ${ }^{7}$ The system character of this precondition for the possibilities of empirical experience is the precondition for the order which we believe to find in experiences and subsequently we believe to find in nature and the nature of things.

\footnotetext{
1 Here we do not use the term "ontology" as it is used in the realm of Computer Science like in Artificial Intelligence, Data Base Technology and others (universe of discourse). We refer to the original term ontology as it is used in Philosophy. Ontology is the teaching about being (Sein) and existing things (Seinendes).

2 Cf. for instance Heraklit: Über die Natur. Fragment 1 and 2. In: Diehls (1922), p. 77; or Fragments 10-13. In: Capelle (1963), p. 131f. For medieval thinkers take for an example Heinrich von Gent (new print 1953 , Vol. 2, 564 ff. Cf. also Hübners article about order (Ordnung) (1984), Sp. 1254-1279.

3 Like the Aristotelian book with the headline de generatione et corruptione.

4 Cf. Leibniz (1958).

5 Cf. Descartes (1644/1965).

6 Cf. Kant (1781/1956).

7 Cf. also Kant (1755/1910).
} 
G. W. Hegel proposed a system of historic development ruled by dialectical laws corresponding to his system of philosophy, ${ }^{8}$ but exactly here we have new development in system ontology. Whereas the order of Descartes' or Kant's system is an order in thought where reason is a matter of concepts about things (on a descriptive level), G. W. Hegel maintained that reason comes to existence, and whatever is existing would be reasonable. Thus Hegel re-ontologized the system concept and again connected the concepts of order (as a metaphor for reason) and existence. From G. W. Hegel to N. Luhmann there is an obvious red line: Systems really exist, they come into existence by their own dynamic and intrinsic laws. ${ }^{9}$ Under this regime $\mathrm{N}$. Luhmann described social systems as genuine existing, autonomous systems with observable properties and recognizable inner structure, regularities and laws of their inner nature.

With this short sketch ${ }^{10}$ we are able to distinguish between two basic system concepts and the following thinkers and authors may be grouped along this classification.

The conceptual order we apply to describe real or intelligible things allows us to use system laws (of formal, logical and mathematical provenience) to make forecasts, explanation, and rules for control and so on of the things described by these concepts. Thus for G. Frege ${ }^{11}$ only Logical Systems, i.e. only conceptual frames were considered as systems. $\mathrm{H}$. Poincaré put forward a more conventionalist variant: Systems as agreed conceptual frame to arrange the manifold of the recognized. ${ }^{12}$ The late M. Heidegger conceived System Theory (Cybernetics) as a Philosophy of Science ${ }^{13}$ and even Habermas regarded systems (i.e. models) as a result gained by systematic method of the researchers. ${ }^{14} \mathrm{H}$. Lenk has analyzed the system concept itself by means of Philosophy of Science and detected that system is a perspectivistic concept. ${ }^{15} \mathrm{G}$. Ropohl developed further the constructivist approach that the researchers' perspective is constitutive for understanding systems. ${ }^{16} \mathrm{E}$. Lazlo has prolonged this idea in order to try to build a Model of Epistemology. ${ }^{17}$

We could also distinguish - as a working hypothesis - the two positions as System Realism (systems are existing in an ontological modus of reality) and System Nominalism (systems are only descriptions of a set of objects, processes, properties as a section of (hypothetical) reality by formal means).

\section{Problems with Naturalizing Systems}

In Philosophy of Science the term "naturalizing something" means to state an existence of something independent from our concepts, consciousness, and cognitive activities. Thus it is a well known principle in classical physics that material objects are existing whether we are observing them or not and whether we have a concept for them or not. In this context such objects belong to nature as far as one is separating nature from man in an epistemological and ontological point of view.

8 Cf. Hegel (1807/1970), p. 11-151.

9 Cf. Luhmann (1984).

10 For a more extensive presentation of the history of system concept cf. Hager (1998), Strub (1998), Schulz (1998).

11 Cf. Frege (1969), Vol. 1.

12 Cf. Strub (1998)

13 Heidegger (1957) pointed out, that a system is encompassing all what can be deduced. The system structures "and moves all knowledge of science, it saves it (the knowledge; the author) and brings it to communication ... it may be conceptualised as the totality of grounding relations, in which the matter of science (as objects, germ.: "Gegenstände"; the author) are represented with respect to its basis, and where they can be understood conceptually" (p. 56) (transl. by the author). Also explicitly pronounced by Heidegger in his famous SPIEGEL Gespräch (1976) with R. Augstein: "What will come after Philosophy? Cybernetics. But this will not be Philosophy anymore." (transl. by the author).

14 Cf. Habermas (1971)(a) and (1971)(b).

15 Cf. Lenk (1978).

16 Cf. his main work $(1979,1999)$.

17 Cf. Lazlo (1972). 
In the history of the system concept, some typical, but different system views have been developed by system researchers and philosophers. The following table compares these system views schematically (to keep it short) with respect to System Realism and System Nominalism.

\begin{tabular}{|c|c|c|}
\hline $\begin{array}{l}\text { Some System } \\
\text { Views }\end{array}$ & System Realism & System Nominalism \\
\hline Atomism $^{18}$ & $\begin{array}{l}\text { Elements, structure and } \\
\text { elementary behavior are real and if } \\
\text { given, the real overall behavior can } \\
\text { be calculated }\end{array}$ & $\begin{array}{l}\text { System description can be } \\
\text { decomposed on an elementary level. The } \\
\text { overall calculation may be successful, if } \\
\text { the object described has only simple } \\
\text { properties }\end{array}$ \\
\hline Holism $^{19}$ & $\begin{array}{l}\text { Concrete systems as wholes are } \\
\text { existing genuine entities, they are } \\
\text { non-decomposable by nature }\end{array}$ & $\begin{array}{l}\text { To treat the basics of such } \\
\text { compositions it is more effective not to } \\
\text { decompose them and to use overall } \\
\text { variables }\end{array}$ \\
\hline Emergentism $^{20}$ & $\begin{array}{l}\text { Real existing systems are } \\
\text { producing new properties that } \\
\text { cannot be understood only from } \\
\text { knowledge about the systems. } \\
\text { A system can be self-generating } \\
\text { by its nature }\end{array}$ & $\begin{array}{l}\text { Emergence is a question of the level of } \\
\text { investigation. Take a system description } \\
\text { as a part of an embedding description, } \\
\text { the emerging properties can be deduced } \\
\text { or forecast. }\end{array}$ \\
\hline Structuralism $^{21}$ & $\begin{array}{l}\text { Systems and Subsystems are } \\
\text { existing independent from each } \\
\text { other. Actual relations can be } \\
\text { assigned by observed interaction }\end{array}$ & $\begin{array}{l}\text { The separation between system and } \\
\text { environment is done according to } \\
\text { interests of the system author. The } \\
\text { description level is chosen in order to } \\
\text { minimize the structural complexity } \\
\text { thereof. }\end{array}$ \\
\hline Organism $^{22}$ & $\begin{array}{l}\text { Each system is part of an } \\
\text { embedding system and contains } \\
\text { embedded systems. The } \\
\text { embedding structure is real }\end{array}$ & $\begin{array}{l}\text { Each system can be described as a } \\
\text { part of an embedding system and may be } \\
\text { conceived to contain subsystems. The } \\
\text { embedding structure is conceptual }\end{array}$ \\
\hline
\end{tabular}

Table 1: System Views with respect to different ontological positions

Needless to say that this table is neither complete nor fully elaborated, but it gives a rough framework for a first orientation in different system ontology's and their system-theoretical consequences.

Actually in sociology and also in biology and physics the naturalization of the system concept can be observed. An obvious social phenomenon like an institution or an organization may be suggestively leading to the concept that there are genuine existing systems, emerging, developing and vanishing again.

18 Early proponents of this view with respect of system realism are Demokritos and Leukippos. Cf. also discussion in Carvallo (1984), with respect of system nominalism there are discussions in Lenk (1978) and Bunge (1977).

19 As a founder of Holism with respect to system realism Haldane (1913) can be regarded. A critique can be found in Bunge (1977), and less critical, Carnap (1975), particular chap. 10.

20 Proponents of this view are Bunge 1978, Bertalanffy (1968).

21 Cf. for Lazlo (1977) (a), (b).

22 Proponents of this view with respect of system realism are Driesch (1928), Hartmann (1953); and with some modifications also Luhmann (1972). For discussion see also Strombach (1983). 
They show a clear cut surface, a border between the inner side of the system and its outside, a constant and easily observable structure and stable behavior. The same holds for biology, observing cells, organs, biotopes and so on. Even in physics each ensemble of particles in thermodynamics is called a real (since physical) system and in technology a circuit or a mechanical or electronic device is called a system.

Despite of all these seemingly advantages of epistemological simplicity gained by this typology, there are a lot of disadvantages of naturalizing systems. They are listed briefly below:

- Danger of essentialism: What is a system really? This does not answer scientific questions like the estimation of dynamics, solutions, stability criteria, conditions of controllability, etc.

- Unnecessary new entities are introduced into the theory (entelechia, vis vitalis, or further emergent properties).

- The prognostic power is not increased, but a stronger explanation power is suggested.

As one can show the naturalizing procedure is only at a first glimpse a trial to bring the description of objects on a physical level, hoping to gain more preciseness and a better theoretical understanding according to the role model of physics, but the epistemological price that has to be paid in order to do so seems to be very high.

\section{The Meaning of Evolution - an Essentialism?}

In order to come to an estimation of this price, we take a look at the concept of evolution. This concept has been put forward not only by $\mathrm{Ch}$. Darwin, since the idea that there is a development as an unfolding of something that is already present but hidden within the inner side and that comes to appearance has already been discussed by the pre-Socrates philosophers. The question is what kind of force and dynamic urges things to unfold hidden properties? Another concept of evolution is the one of implicit emergence. The development is not an unfolding of already existing but hidden properties but a coming into existence of new objects, processes and properties. Again the question arises: what brings the new, not already existing things, processes and properties into their existence? Here the answers of the pre-Socrates philosophers differed considerably.

The concept of Darwinian evolution was developed along the biological "systems" and it made the term popular and applicable also to other fields like sociology, technology, ecology, and even philosophy (evolutionary epistemology). The history of the human mind was conceived as an evolutionary process, the categories and Anschauungsformen by Kant were interpreted as a result of mutation, selection, and isolation. And the analogy of evolution could also be applied on the history of ideas during the history of philosophy. The same may hold for the "Evolution of System Thinking".

Beside this main stream of contemporary philosophy one can go back to the pre-Socrates question: If Ch. Darwin describes species as a kind of system that evolves in time, driven by selection mechanisms, the new properties are generated by chance, i.e. mutations that are mostly distortions of the genetic information within the organism. The new property that has been generated is unfolded only if it proves to be advantageous for the survival of the species, otherwise it will never appear. But it is already existent. Thus the driving force is chance, combined with a necessity that is contingent by the actual existing boundary condition of the relevant species. In the public discussion about an egoistic gene one of the metaphors that came into play has caused a lot of confusion: it depends considerably on which level one presumes that new properties are generated.

If one talks about the evolution of systems within this realm, a certain naturalization of the system concept is already presupposed, otherwise speaking about this topic may be not very meaningful. If then 
system realism is assumed, evolving systems must be explained by isolation, selection and variation (mutation). But what is the driving mechanism for such processes? In biology we have the quantum mechanical probability that the copy process during the replication of DNA is never perfect and that radiation, heat, and chemical influences endanger the integrity of the stored DNA within the cell. With respect to systems one can generally say that evolving systems must be considered either as organs in an individual like a member of an evolving species or that essential properties must emerge. Again we have the question what the driving forces of this emergence are and where they come from.

We could answer that it is a genuine task of system theory to develop exactly such a theory and that General System Theory could be one of the candidates to do this. On the other hand, if the meaning of emergence is not clarified, we run into a lot of obstacles. First of all, the coming into existence of a new property has frequently become explainable if one took into account an embedding super-system. Even in biology one was able to understand the unfolding of new properties as a consequence of molecular dynamics in an embedding world with certain chemical and thermodynamic conditions that facilitate the game of mutation and selection already on a pre-biotic macromolecular level. Therefore, the shift of the system border to an embedding system and the assumption that each system is a subsystem of another one, violates the genuine issues of the system in quest. Thus one either leaves the system realistic standpoint and concedes that one must shift to the level of description in order to get an explanation for the becoming of new properties and entities or one looks for inner forces within the system in order to explain emergence. ${ }^{23}$

These inner forces or causes are then believed to belong essentially to the system, its own nature and characteristics. Therefore we could pose the provoking question: Is General System Theory an essentialist theory and therefore an unscientific project?

Essentialism has been defined as an Aristotelian view of nature. The philosopher asked: What is the nature of a tree, which properties are sufficient to recognize a tree as a tree and which basic properties, i.e. essentials, must it possess to be a tree? The answer was that not outer properties like branches, green leaves and so on make a tree to a tree, but that the tree is consisting on what Aristotle called substance, i.e. that which is lying beyond all outer properties and makes a thing consisting of this substance a tree and nothing else. This substance is the bearer of the essence of a tree. ${ }^{24}$

Essentialist theories, like Aristotelian physics are, for example, the learning about Vitalism, explaining natural processes by immanent entelechia ${ }^{25}$ or vital forces.$^{26}$ Essentialist theories use to introduce new basic concepts, mostly such ones that are entities on an ontological level - these entities are maintained to exist really. Some basic characteristics may be listed:

- It is possible to distinguish between essential and accidental properties.

- To each object (or calls of objects) a different entity is ascribed.

- Essentialism (in current interpretation) is dealing with concepts like to believe, to will, to strive, to love, to hate, etc. (intensional predicates).

- This is regarded not to be logically satisfying, since within intensional contexts there is no application of the principle of substitution: concepts cannot be substituted by identical concepts without violating the preservation of truth.

- No referential meaning can be defined by any determination of essentialist entities.

23 Cf. also Kornwachs (1996).

24 Cf. Aristotle Metaphysics 1029 b. $\tau$ o $\tau \imath \varepsilon v \varepsilon ı v \alpha ı$ (gr.) as essence or "Wesenswas"(germ.)

25 Cf. Aristotle Metaphysics, Book IX, 1047-1050 ff.

26 Cf. again Driesch (1909). 
In a strong opposition to this, a (very) positivistic interpretation of science may be mentioned. Only entities are real (in a sense not defined further) that can be observed and measured, i.e. to play a role as a variable. This radical position denies that there are intentional objects like feelings; these terms are only accessible by introspection, but not verifiable by observation. They cannot play the role of a variable. Such presuppositions would be unscientific and fruitless. Moreover, any progress in psychology would be prevented by stating such unobservable entities. Taking this view one may ask whether there is only one true description or theory of the universe? The radicalism of this position caused a certain attenuation of the positivistic claims. An answer to this rigid philosophy of science was a more anarchic and very pragmatic point of view: It should not matter how a theory explains the phenomena as long it is done successfully. The question remains of course whether General System Theory (GST) is really explaining phenomena successfully and satisfyingly.

Nevertheless it may be a good idea to check whether GST is using teleological explanations and postulating aims, goals and intentions. GST is not using teleological explanation in the sense that systems would have intrinsic motivations or intentions. But in an operative way it is possible to model goals as a control parameter for instance in a control circuit. This control parameter is "given from outside" of the system.

When Bertalanffy is speaking about equifinality, ${ }^{27}$ he is classifying a sort of behavior that can be modeled by complexly nested control circles that are self-optimizing in a stable way, i.e. approaching the same attractor independent from the point of start within the state space.

To be fair, it is known that a certain façon de parler in physics sounds like teleological principles. Even physics is applying aims and goals when describing natural processes. So the Law of LeChâtelier, i.e. the principle of the least force/action (Prinzip des kleinsten Zwanges) and Lagrange's formulation of the principle of shortest path includes terms of intentions or goals, set by nature, to be fulfilled by each process. But the formulation allows to be deduced from a mathematical formulation of the principles of conservation (minimal problems) or from the correct equation of motion. In other words: These principles are not necessary to erect the theoretic building of classical mechanics. So they may serve as an illustration or as a metaphor, but they can be omitted without damage for the theory and therefore they are candidates to be cut by Ockham's razor.

\section{Bertalanffy's View}

It may be surprising that Bertalanffy had some similar views like Hans Driesch and others, assigning them as "organism view".$^{28} \mathrm{He}$ pointed out that the difference between vitalism and mechanism could not yet be solved. He was looking for "gebietseigene Gesetze" (genuine laws) in Biology, since both vitalism and mechanism were considered by him as a solution to explain the observation of partial and sectoral processes. ${ }^{29}$ According to Bertalanffy therefore vitalism should describe in this view a physico-chemical process + entelechia). ${ }^{30}$

So Bertalanffy preferred a holistic view ("ganzheitliche Betrachtungsweise") against an analytical system view, that only considers sums ("summativ"), and he preferred the dynamic view against a static or machine oriented view. He saw an organism as a primordial activity instead of a pure reactivity of the organism ("Betrachtungen des Organismus als einer primären Aktivität gegenüber der Auffassung von der

28 Cf. Bertalanffy (1926). The following citation of early Bertalanffy in this chapter has been inspired by the summarizing contribution of Unger(1942).

29 Cf. Bertalanffy (1927/1928).

30 Cf. Bertalanffy (1937). 
primären Reaktivität des Organischen"). For him, all these were basic principles of a holistic and organism view ("Leitsätze einer ganzheitlichen und organismischen Auffassung"). ${ }^{31}$

This Auffassung does not yet provide an explanation, but a more precise characterization ("Kennzeichnung") of the actual and observable facts. It shows the limits of the causal and mechanistic views regarding only particular things. It paves the way for a progressing explanation by hypothetical lawlike regularities.

Bertalanffy proposed also to restrict the research on the empirical basis and keep it free from metaphysical prejudices and presuppositions. Bertalanffy's theoretical biology ${ }^{32}$ aimed primarily at erecting a system with strict logical rules that should have the same rank and the same relation to empirical statements and observable facts in Biology like theoretical physics has a relation to experimental physics. $\mathrm{He}$ was convinced that there is a holistic genuine lawfulness of the organic ("ganzheitliche Eigengesetzlichkeit des Organischen")

The exploration of the order (structure) of elements and processes of life that are reaching beyond the inorganic level is a main task of biology. A singular causal analysis or investigation is no more possible, hence number and complexity of the singular processes make it impossible when trying to explain the whole organism. Laws and rules for genuine biological processes and basic problems like metabolism, growth, shaping of forms, "Gestalt". ${ }^{33}$ I will come back to these forms (Gestalt) as the most striking phenomena of "emerging" systems and as a strong argument that a system is genuine on an ontological level.

Bertalanffy's basic traits of systems in Biology are well known: Each organism is an open system. Within this concept, the dynamical equilibrium, the steady state far from thermodynamic equilibrium can be defined, ${ }^{34}$ catalytic reactions, controlling distortions, noise, etc. are keeping the surface of the system constant. The system cares for the deliverance of energy and it behaves according to the principle of equifinality (Unger 1942).

In his later comprehensive view, Bertalanffy ${ }^{35}$ proposed a system ontology with three levels. These levels differ with respect to different regards of reality. Here already the distinction of the perspectives of the observer and the system analyst came into play:

Real Systems:

All the entities, that can be observed by the observer, are independent from him and the particular situation

Conceptual Systems Symbolical Structures, like Mathematics, Logics, etc.

Abstract Systems:

They are included within the conceptual systems as far as they can be mapped on real systems.

Is it now possible to mediate between the worthy approaches put forward by Bertalanffy (1968) and a modern analytical view of science and system theory?

31 Cf. Bertalanffy (1928).

32 Cf. Bertalanffy (1932).

33 Cf. Unger (1942), S. 83, 84. Cf. also Bertalanffy (1929) and (1931, 1932).

34 Bertalanffy (1950) was one of the first theoreticians who put forward the idea that biological systems cannot be regarded as closed systems with the second theorem of thermodynamics, as done later and made more precisely by Meixner (1943), Glansdorf/Prigogine (1971), Prigogine (1972), and others.

35 Cf. Bertalanffy 1968, p. 14 ff. 
Bertalanffy is frequently considered as having completed the program of theoretical biology by surmounting the contradiction between mechanism and vitalism. ${ }^{36}$ His holistic and organic view ${ }^{37}$ is directed against reductionism, machine theories of life and metaphysical vitalism.

"Unsere Aufgabe muss es vielmehr sein, die Lebewesen als Systeme besonderer Art von in dynamischer Wechselwirkung stehenden Elemente zu betrachten, und die hier geltenden Systemgesetze zu ermitteln, welche die Ordnung aller Teile und Vorgänge untereinander beherrschen “38 (Bertalanffy 1937, p. 12).

This leads to a modified concept of teleology, named equifinality. ${ }^{39}$

\section{The Constructivist Approach}

The basic question for any system scientists is: What is an open system? Can it be detected by observation? Different answers and positions with respect to this question that can be related to certain philosophical positions in epistemology and ontology, have been developed. ${ }^{40}$

A possible answer according to Kant could be: If the concept of open system is already available, open systems will be observed some day. The concept of openness and "systematicity" would then be necessary categories (prior to all experience) to make experiences with such kind of systems. ${ }^{41}$ One could argue that the capability to be a system owns to certain sections from reality that can be better described by system theoretical concepts (i.e. using mathematics) than other description instruments. But this "systematicity" seems to be a condition of possibility to regard something as a system. The same holds for "openness" or other intelligible concepts in this field.

The answer of Thermodynamic $(T h D)$ is well known: If the parts of the system can be described like Non-equilibrium ThD does, the system can be calculated like a ThD-System. Some basic traits can be explained (entropy differences, phase space, ergodicity, generation of structures from chaotic dynamics, etc.), others not (like reduplication or feedback control and others).

The constructivist approach, as put forward by Heinz von Foerster and others ${ }^{42}$ can be pinpointed as follows:

- What we can observe is calculated according to our sensual data, using already existing or imagined models. It may be that new models can be generated, but they need already existing pre-models that can be developed further. The model may be delivered by Kants's Anschauungsformen and categories as well as by inner structures (innate structures) that have been developed during evolution.

- The justification or validation of the model is only given by the success of dealing with it (survival). Nothing is told about the world or any reality, only about the success of constructed models.

36 Cf. Schulz (1998), Sp. 859.

37 Cf. Bertalanffy (1937), p.. 14.

38 cited according to Schulz (1998), p. 859. "It should be our task to conceive living entities as systems of particular kind with dynamically interacting elements, and to investigate the valid system laws which rule the order between all parts and processes." (transl. by the author).

39 Cf. Bertalanffy (1937), p. 14. Cf. also Bertalanffy (1942 / 1951), pp. 64-68.

40 In the realm of system theory itself there are very precise definitions in GST of open and closed systems: Bertalanffy's concept of "Fließgleichgewicht" (1968), Prigogine's definition of open systems far from equilibrium (1950) (this equilibrium can be defined not only for thermodynamic systems), Mesarovic's definition (1972), and a first approach for open systems as changing and therefore with self-reference systems by Kornwachs (1987), pp. $258 \mathrm{ff}$.

41 To avoid misunderstandings: Kant didn't mention any categories or Anschauungsformen (forms of perception) like openness and systematicity. But concepts like that could play a role of such Anschauungsformen using Kant's point of view.

42 Cf. Foerster (1973/1994). 
- Open Systems is a concept that is more or less successful to handle with biological entities.

The disadvantages of these three types of views can be shortly summarized. It can be shown that a radical constructivist approach does not allow to separate between prescriptive and descriptive terms, since the criterion is only the success of handling models. Models are described mostly as systems, but the models also act as prescription of how to act in a world that is modeled according to the model. Thus only calculation can be controlled by calculation.

The pure thermodynamic approach is not able to explain how information works (like in biology), this approach puts forward only the physical preconditions of physical systems that are able to perform information or neuronal processing.

The disadvantage of Kant's approach can be shown by the aleatoric choice of concepts for the role of categories and Anschauungsformen. It cannot prevent that we only may observe what fits to be observed by a contemporary realm of concepts. Thus, surprising detections and observations that put forward science and technology would be impossible.

\section{Descriptionism - Proposed and Revisited}

I want to introduce here a position that may be called descriptionism. It is another view on systems and system theory that differs from the pure positivistic, constructivist or the radical naturalistic ones discussed above. It tries to avoid the epistemological and analytical disadvantages of such positions.

The basic assumption (or axioms) of descriptionism can be sketched as follows:

Every modeling of a relevant phenomenon as a section of reality (whatever this means) is an act which is purposeful and which has an intention. The intentions of modeling can be figured out by the different forms of use of the model: In order to control, to explain, or to forecast the behavior of the system.

The very act of modeling draws inevitably a border line between what is belonging to the system and what is not belonging to it. It constitutes the difference between inside and outside (exo - endo cut). Therefore this cut expresses an interest to warrant modeling even in this area and not in another one. So each system as a description has an author which pursues certain interests.

This seems to be obvious in system theory, but philosophy of science has discovered this main characteristics in all scientific modeling. In other words: System Theory is a certain kind of Philosophy of Science. We can describe physics for instance as a system theoretical modeling of certain processes and objects in which we are interested.

General System Theory is therefore a means for description (with many tools, mainly mathematical ones), and to perform a mathematization of different areas of interest. Areas, taken from the real world, described as systems, seem to behave like genuine entities. We are talking about those entities as they were existing systems in a basic ontology. Nevertheless we should bear in mind that our description is producing the conditions that a description (using GST) is an adequate or useful model of an area of interest.

Reality, conceived as the comprehensive term of independently existing circumstances, can be hypothesized, but without observing and describing it, nothing is known about it. Any observation presupposes basic concepts that have their origin in a previous description (pre-theory). 


\section{System Surface, Modeling and Control}

But one problem has not yet been solved by descriptionism: This is the question of how we can observe obviously or seemingly existing surfaces, i.e. how can borders between the inner and the outer side of objects and "systems" as objects, processes or ordered set of them, be described as systems?

To solve this problem, we may make a very rough distinction between different types of how a surface is constituted.

System surfaces, recognized by observation like with simple objects. It seems to be clear that there is a clear border line between the box (as a synonym for an object) and its environment. The simple square in Fig. 1 may symbolize this isolation from a surrounding environment. The observation can be verified by stating that a selected property (value of a variable) is changing if one passes the border line, symbolized by the arrow (like color etc.)

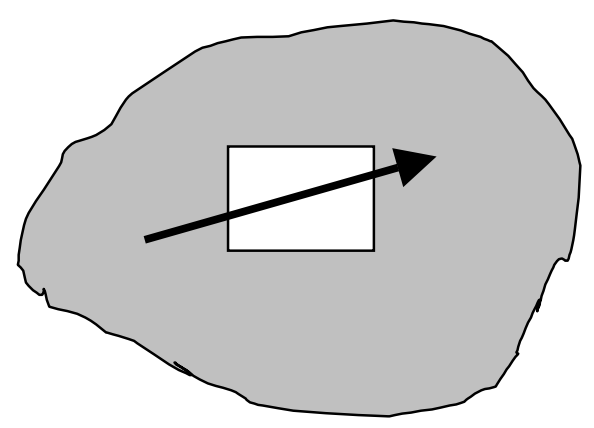

Figure 1: Isolated "object"

The constitution of a system surface by experience is related to the difference between "inner -outer" or "inside - outside". Here not a variable changes its value passing the borderline, but the system is constituted by the experiences one can made with "it" as a quasi object or process. The experience can be expressed in terms like behavior or input-output relations etc., but this constitution is an implicit one. 


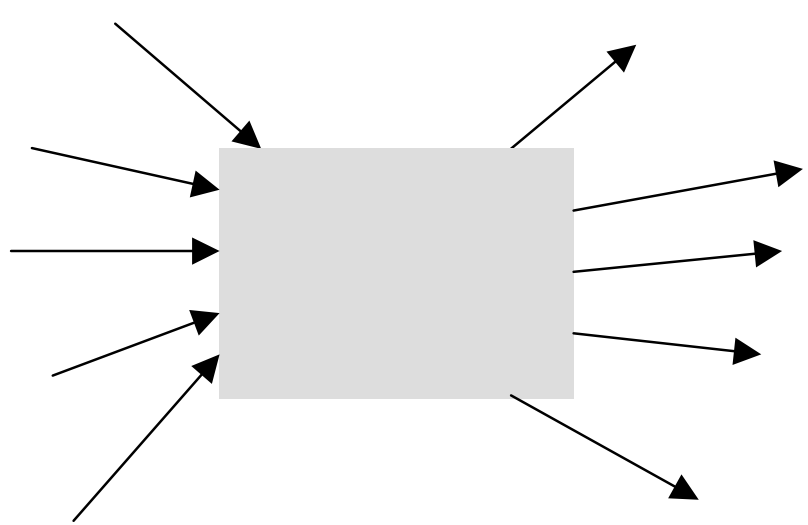

Figure 2: Implicit Surface of a System

The ingoing arrows in Fig. 2 may be interpreted as independent influences (variables), the outgoing arrows as the resulting or dependent variables The selection of the set of variables constitutes the functional surface of the system.

The constitution of the system surface by description (Endo - Exo) presupposes both of the forgoing procedures: Variables and properties are selected and the embedding of the system within a supersystem and the division into subsystems is already a result of a system analysis that is already a system description. At this point we may distinguish between an inner surface (the surface observed from inside) and an outer surface (the surface observed from outside), suggested by Fig. 3.

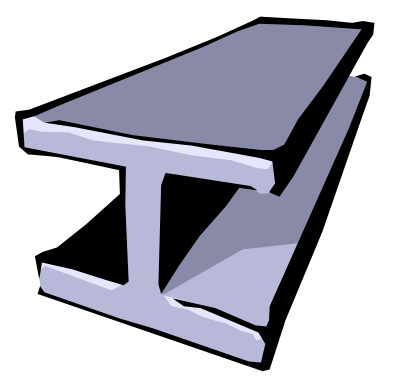

Figure 3: Object / System with Inside / Outside Surface

At this very point one could argue that there are seemingly ontological system surfaces. In Table 2 such kinds of system surfaces are listed. 


\begin{tabular}{|c|c|c|c|}
\hline System Type & Inner Surface & Outer Surface & Transfer by \\
\hline EDP, Computer & $\begin{array}{l}\text { Layer behind I/O- } \\
\text { elements, compiler }\end{array}$ & $\begin{array}{l}\text { Screen, display, keyboard, } \\
\text { sensors }\end{array}$ & Signals \\
\hline Biology & $\begin{array}{l}\text { Organ surface, } \\
\text { membranes }\end{array}$ & Epidermis, skin & $\begin{array}{l}\text { Metabolism, diffusion, } \\
\text { osmotic process }\end{array}$ \\
\hline Physics & $\psi$ - Function & Observable & Measurement \\
\hline Technology (Car) & Motor surface & Instrument panel & $\begin{array}{l}\text { Sensors, actors (force } \\
\text { transmission) }\end{array}$ \\
\hline Organization & Procedure & Legality & Decisions \\
\hline Networks, Nets & Connectivity & Devices & Information \\
\hline General Systems & State $\rightarrow$ signs & Signals $\rightarrow$ information & $\delta$-, $\lambda$-function \\
\hline
\end{tabular}

Table 2: Surfaces of different System Types. According to the different surfaces the transfer of material, information and energy flow may be observed

A possible answer to this serious objection could be: It is not the system description that induces a surface or the border of inner and outer side, but we choose a system description which runs along (mostly) the ontological given surfaces of already separated objects or objects separable by us. The reason for that is quite simple: We try to get descriptions that are easy and simple in order to be proceeded further with a minimum of effort. It seems to be that one hopes that surfaces in system theory, that are designed according to ontological surfaces, are simpler than other ones. Indeed, in an overwhelming number of examples this is the case. But we should not be worried about counterexamples.

Thus the border lines between exo and endo can be drawn with more advantage (i.e. the mathematics of the description becomes simpler), if one takes the choice with respect to the aimed function of the model instead of taking the surface that is given by phenomenology. ${ }^{43}$

The advantage of adaptedness of a system choice (i.e. model building decisions) depends extremely on the use of the system description the author has in mind (explanation, forecast, simulation, control, etc.)

\section{The Reality of Descriptions}

The application of descriptionism confronts us with an ancient belief according to which science would be a value neutral tool. If one can show that the design of borderlines and surfaces depends on the selected intention of the use of system description, than one could suspect that the use of goals and intentions as variables would also include prescriptive values.

But even natural science has been proved not to be value neutral, as it has been shown by the analysis of Thomas S. Kuhn (1973), Imre Lakatos (1974) and others. Each physical theory has presuppositions that are not completely value neutral like simplicity of theory, preciseness, freedom from contradiction, and success in working with it, a certain explanatory force and others. Any selection of important and unimportant observation ("essential" data and data trash), the relation between observation and fact, the decision what can be regarded as boundary condition and what as a genuine process, ruled by natural laws, is theory laden. Even in physics the border lines between the observed system and what is not taken into account by a researcher, is a normative, value driven decision.

43 Cf. also Kornwachs (1996). 
In modern system theory, for instance applied in the realm of technology assessment, the concept of teleology has been substituted by the concept of teleonomy. Here, aims, goals, intentions etc. can be easily eliminated and substituted by causal descriptions. ${ }^{44}$ In modern system theory there is no more any essentialist entelechia detectable. But this doesn't prevent that prescriptive elements determine the model building process to a considerable extent, whereas the model itself can be formulated as a pure causal model, describing a system, embedded and isolated in its environment.

As a suggestion three final hypotheses are proposed:

H1. The different interpretations of System Theory are so numerous as the interpretation of Quantum Theory. Quantum Theory expresses the conditions for the possibility of experimental (physical) experience. One could even argue that Quantum Theory is a very special kind of System Theory. ${ }^{45}$ It works without interpretation with only few exceptions.

H2. System Theory expresses the conditions of possibility of describing models for experience and models of ideas as well.

H3. System Theory as a means for description cannot tell us how to shape the world, community, and peace. It helps us to change the design of our concepts, describing successfully the world. The way we are performing our model building and the selection of important and unimportant issues reflects the way we are considering the world with respect to not only what could be the case but also with respect to the question: What should be?

\section{References}

Bertalanffy, Ludwig von (1926) Zur Theorie der organischen Gestalt. In: Arch. Entwicklung Mech. 108 (1926)

Bertalanffy, Ludwig von (1927/28) Studien über Theoretische Biologie. In: Biologisches Zentralblatt 47(1927, 1928)

Bertalanffy, Ludwig von (1928) Kritische Theorie der Formbildung. In: Abhandlungen zur Theoretischen Biologie 27(1928)

Bertalanffy, Ludwig von (1929) Die Teleologie des Lebens. In: Biologia Generalis V (1929)

Bertalanffy, Ludwig von (1931/32) Tatsachen und Theorien zur Formbildung als Weg zum Lebensproblem. In: Erkenntnis I $(1931,1932)$

Bertalanffy, Ludwig von (1932) Theoretische Biologie I. Berlin. Borntraeger.

Bertalanffy, Ludwig von (1937) Das Gefüge des Lebens. Leipzig. Teubner

Bertalanffy, Ludwig von (1940) Der Organismus als physikalisches System betrachtet. In: Die Naturwissenschaften 28 (1940), pp. $511-531$

Bertalanffy, Ludwig von (1942) Theoretische Biologie II. 1942, 2nd edition 1952. Bern. Francke.

Bertalanffy, Ludwig von (1950) The Theory of Open Systems in Physics and Biology. In: Science 111 (1950), January, pp. 23 - 29

Bertalanffy, Ludwig von (1968/73) General System Theory. Hammondsworth, GB. Penguin Books

Bertalanffy, Ludwig von (1972) The History and the Status of General System Theory. In: Klir, G. J. (Ed.) (1972) Trends in General System Theory. New York/London. Wiley Interscience. pp. 21- 41.

Bunge, Mario (1967) Scientific Research I - The Search for System. New York/Heidelberg/Berlin. Springer.

Bunge, Mario (1967) Scientific Research II - The Search for Truth. Berlin/Heidelberg/New York. Springer.

Bunge, Mario (1979) A Treatise on Basic Philosophy. Vol. IV. A World of Systems. Dordrecht/Boston. D. Reichel.

Bunge, Mario (1977) General Systems and Holism. In: General Systems Yearbook 22 (1977), pp. 87 - 90

Capelle, Wilhelm (1963) Die Vorsokratiker. Stuttgart. Kröner.

Carnap, Rudolf (1969) Einführung in die Philosophie der Naturwissenschaft. München. Nymphenburger.

Carnap, Rudolf (1971) Scheinprobleme in der Philosophie. Frankfurt/Main. Suhrkamp.

Carvallo, Marc E. (1984) Chance and the Necessity of the Third Classical Paradigm. In: Trappl, Robert (Ed.) (1984) Cybernetics and System Research 2. North Holland, Amsterdam. Elsevier.

44 Cf. Zoglauer (1996).

45 Proposed in many discussions by Francis H. Zucker. Cf. Zucker (1974), (1978) and in later manuscripts never published and lost. It is not the place here to fortify this hypothesis, but it is easy to reformulate the basic axioms and theorems of Quantum Mechanics in terms of system theory (state space approach). 
Descartes, René (1965) Die Prinzipien der Philosophie (1644). Hamburg. Meiner.

Diehls, Hermann (1922) Die Fragmente der Vorsokratiker, Bd. 1-2. 4th edition. Berlin. Weidmannsche Buchhandlung

Driesch, Hans (1909) Philosophie des Organischen (2 Bde.). Leipzig. Engelmann.

Fichte, Georg (1794) Über den Begriff der Wissenschaftslehre oder der sogenannten Philosophie (Weimar 1794). In: Werke 1793 1795, Gesamtausgabe, hrsg. von der Bayerischen Akademie der Wissenschaften Bd. 1.2 Stuttgart-Bad Cannstatt. FromannHolzboog, 1965

Foerster, Heinz von (1973) On Constructing a Reality. In: Preiser, W.F.E. (Ed.) (1973) Environmental Research, Vol. 2. Stroudberg, pp. 35-46. German in: Foerster, Heinz von (1994) Wissen und Gewissen. Frankfurt/Main. Suhrkamp, pp. 25-49.

Frege, Gottlob (1969) Logik in der Mathematik. In: Nachgelassene Schriften, hrsg. von H. Hermes, F. Kambartel und F. Kaulbach; 1. Band. Hamburg. Meiner. 1969

Gent, Heinrich von (1953) Summa Theologiae; Vol 2. New Print.

Glansdorff, Paul/Prigogine, llya (1971) Structure Stabilité et Fluctuations. Paris. Masson. engl: Thermodynamic Theory of Structure. Stability and Fluctuations. London. Wiley \& Sons, 1971

Habermas, Jürgen (1971a) Erkenntnis und Interesse. Frankfurt/Main. Suhrkamp.

Habermas, Jürgen (1971b) Theorie der Gesellschaft oder Sozialtechnologie? Einleitung. In: Habermas, Jürgen/Luhmann, Niklas

(1971) Theorie der Gesellschaft oder Sozialtechnologie. Frankfurt/Main. Suhrkamp, pp. $142 \mathrm{ff}$.

Hager, F.-P. (1984) System. I. Antike. In: Ritter, J/Gründer, K. (Eds.) (1984) Historisches Wörterbuch der Philosophie, Bd. 10.

Darmstadt. Wiss. Buchgesellschaft, pp. 824-825.

Haldane, John Scott (1913) Mechanism, Life and Personality.

Haldane, John Scott (1931) The Philosophical Basis of Biology.

Hartmann, Max (1953) Allgemeine Biologie. Stuttgart. Fischer.

Hegel, Georg W. F. (1807) Phänomenologie des Geistes. Vorrede (Bamberg, Würzburg 1807). Frankfurt/Main. Ullstein, 1970, pp. 11-15.

Heidegger, Martin (1957) Identität und Differenz. Pfullingen. Neske.

Heidegger, Martin (1987) „Nur ein Gott kann uns retten.“ SPIEGEL-Gespräch mit R. Augstein. In: DER SPIEGEL No. 23/1976 (1987), p. 209.

Hübner, W. (1984) Ordnung. II. Mittelalter. In: Ritter, J./Gründer, K. (Eds.) (1984) Historisches Wörterbuch der Philosophie, Bd. 6. Darmstadt. Wiss. Buchgesellschaft, Sp. 1254-1279

Kant, Immanuel (1755) Allgemeine Naturgeschichte und Theorie des Himmels oder Versuch von der Verfassung und dem mechanischen Ursprung des ganzen Weltgebäudes, nach Newtonschen Grundsätzen abgehandelt (Königsberg, Leipzig 1755). In: Gesammelte Schriften hrsg. von der Kgl. Preuß. Akad. der Wissenschaften. Berlin. Georg Reimer, 1910.

Kant, Immanuel (1956) Kritik der reinen Vernunft. Riga 1781. Hamburg. Felix Meiner, Bd. 37a, 1956

Kornwachs, Klaus (1987) Offene Systeme und die Frage nach der Information. Habilitation Thesis. University of Stuttgart.

Kornwachs, Klaus (1996) Pragmatic Information and System Surface. In: Kornwachs, K./Jacoby, K. (Eds.) (1996) Information - New Questions to a multidisciplinary Concept. Berlin. Akademie, Berlin, pp. 163-185

Kornwachs, Klaus (1998) Pragmatic Information and the Emergence of Meaning. In: Van de Vijver, G./Salthe, S./Delpos, M. (Eds.) (1998) Evolutionary Systems. Boston, Mass. Kluwer, pp. 181-196.

Kuhn, Thomas S. (1973) Die Struktur wissenschaftlicher Revolution. Frankfurt/Main. Suhrkamp, 2nd edition.

Lakatos, Imre (1974) Die Geschichte. der Wissenschaft und ihre rationale Rekonstruktion. In: Diedrich, W. (Ed.) (1974) Theorien der Wissenschaftsgeschichte. Frankfurt/Main. Suhrkamp, pp.. 55-119.

Lazlo, Ervin (1972) Introduction to System Theory. New York. Gordon \& Breach.

Lazlo, Ervin/Margenau, Henry (1972) The Emergence of Integrative Concepts in Contemporary Science. In: Philosophy of Science 39 (1972/2), pp. 252-259.

Leibniz, Gottfried W. v. (1958) Monadologie. In: Leibniz-Hauptwerke. Hrsg. von G. Krüger. Stuttgart. Kröner Verlag, pp. 131-150.

Lenk, Hans (1978) Wissenschaftstheorie und Systemtheorie. In: Lenk, Hans/Ropohl, Günter (Eds.) (1978) Systemtheorie als Wissenschaftsprogramm. Königstein. Athenäum-Verl., pp. 239 - 269

Luhmann, Niklas (1984) Soziale Systeme. Frankfurt/Main. Suhrkamp.

Meixner, Josef (1943) Zur Thermodynamik der irreversiblen Prozesse. In: Zeitschrift für physikalische Chemie (B) 53 (1943), pp. 235, 238-242.

Mesarovic, Mihajlo D (1972) A Mathematical Theory of General Systems. In: Klir, George (Ed.) (1972) Trends in General System Theory. New York/London/Sydney/Toronto. Wiley-Interscience, pp. 251-269.

Prigogine, llya (1972) Information. In: Scharf, J.H. (Ed.) (1972) Informatik. In: Nova Acta Leopoldina 37 (1972/1), Neue Folge, Nr. 206, S. 143 - 150, Halle 1972

Ropohl, Günter (1979) Systemtheorie der Technik. München. Hanser; 2nd edition: Allgemeine Technologie. München. Hanser, 1999.

Schulz, R. (1984) Systeme, biologische. In: Ritter, J./Gründer, K. (Ed.) (1984) Historisches Wörterbuch der Philosophie, Bd. 10.

Darmstadt. Wiss. Buchgesellschaft, 856-862.

Strombach, Werner (1980/81) Philosophische Aspekte der Informatik. In: philosophia naturalis 18 (1980/1), pp. 181-194.

Strub, Ch. (1984) System. II. System und Systemkritik in der Neuzeit. In: Ritter, J. Gründer, K. (Eds.) (1984) Historisches Wörterbuch der Philosophie, Bd. 10. Darmstadt. Wiss. Buchgesellschaft, 825-856. 
Ungerer, E. (1942) Die Erkenntnisgrundlagen der Biologie. Ihre Geschichte und gegenwärtiger Stand. In: Bertalanffy, Ludwig von (Ed.) (1942) Handbuch der Biologie. Bd. I: Allgemeine Biologie, Erster Teil. Potsdam. Akad. Verlagsgesellschaft, Athenaion, pp. 194.

Zoglauer, Thomas (1996) Can Information be naturalized? In: Kornwachs, Klaus/Jacoby, K. (Eds.) (1996) Information - New Questions to a multidisciplinary Concept. Berlin. Akademie, pp.187-207.

Zucker, H. F. (1974) Information, Entropie, Komplementarität und Zeit. In: Weizsäcker, Ernst U. von (1974) Offene Systeme I. Stuttgart. Klett. pp. 35-81.

Zucker, H. F. (1978) Phenomenological Evidence and the „Ideal“ of Physics. Working Paper, Max Planck Institut zur Erforschung der Lebensbedingungen, Starnberg, presumably 1978 